\section{Inheritance of Albinism in Banana and Plantain (Musa spp.) and its Significance in Breeding}

\author{
Rodomiro Ortiz ${ }^{1}$ and Dirk R. Vuylsteke ${ }^{2}$ \\ Plantain and Banana Improvement Program, International Institute of Tropical \\ Agriculture, Onne Station, PMB 5320, Ibadan, Nigeria
}

Additional index words. embryo culture, phenotypic recurrent selection, recessive deleterious alleles

Abstract. Few genetic markers are available in Musa spp. as a result of a lack of inheritance studies. Full-sib diploid $(2 \mathrm{n}=\mathbf{2 x}=\mathbf{2 2})$ plantain-banana hybrids of the International Institute of Tropical Agriculture were selfed or outcrossed with other diploid bananas, one of which is an improved selection from Central America. Three populations having albinos (complete lack of chlorophyll in any plant tissue) were produced. The segregation ratios for albinism suggested that this deleterious trait is controlled by one or two recessive alleles. The small sample sizes (a problem inherent in the low reproductive fertility of cultivated parthenocarpic Musa) in two of these three populations did not allow for conclusiveness between the one or two genes model. However, a distinction was possible with the third population, consisting of 64 seedlings, of which four were albinos. The segregation ratio for albinism fit the $15: 1$ ratio $\left(\chi^{2}=0.07, P=0.79\right)$ and not the $3: 1$ ratio $\left(\chi^{2}\right.$ $=11.02, P<0.01$, suggesting that albinism in Musa spp. is under the genetic control of at least two independent recessive alleles with complementary gene action. This finding also demonstrates that deleterious recessive alleles are present in the cultivated $\mathrm{AAB}$ plantain gene pool and in cultivated and advanced AA banana breeding populations. The latter suggests that population improvement through phenotypic recurrent selection for agronomic traits might be based on the elimination of deleterious recessive genes.

Banana and plantain, when considered together (Musa spp. L.), are among the 10 most important food crops of the world. They are a principal source of carbohydrates and calories, particularly for domestic consumption in the producing tropical countries, as only $10 \%$ of world production ( $\approx 70$ million tons) enters the export market.

Few genetic studies have been undertaken in Musa spp. despite the importance of the crop. Simmonds (1953) elucidated the genetic system controlling fruit parthenocarpy (at least three independent dominant $P_{i}$ genes with complementary gene action) and persistence of bracts and flowers in the male part of the inflorescence axis (complementary gene control).

Several characteristics inherent in the crop constrain the breeding and genetic analysis of Musa spp. The bulk of cultivated bananas and plantains are triploid $(2 n=3 x=33)$ and have very low reproductive fertility. The low rate of hybrid progenies recovered and the resulting small sample sizes are the major obstacles to

Received for publication 14 June 1993. Accepted for publication 19 Jan. 1994. We thank Leo Oragwa for assistance in embryo culture. The cost of publishing this paper was defrayed in part by the payment of page charges. Under postal regulations, this paper therefore must be hereby marked advertisement solely to indicate this fact.

${ }^{1}$ Breeder and Geneticist.

${ }^{2}$ Germplasm Enhancer. International mailing address: IITA, c/o L.W. Lambourn \& Co., Carolyn House, 26 Dingwall Road, Croydon CR9 3EE, England.

HortScience, Vol. 29(8), August 1994 a plantain and banana improvement program aimed at host plant resistance to black sigatoka (Vuylsteke et al., 1993a, 1993b). Alongside this primary target, which is one facet of disease pressure, other traits are also evaluated and analyzed to acquire a better understanding of Musa genetics. The Onne station of IITA in Nigeria seems to provide a suitable environment for seed production in cultivated Musa (Swennen and Vuylsteke, 1990, 1993), which allows the production of adequate numbers of hybrid progenies necessary for genetic studies.

This paper reports on the occurrence of albinism in Musa hybrids, determines the inheritance of this trait, and briefly discusses this finding in relation to the genetic structure and the current breeding methods in Musa spp.

\section{Materials and Methods}

The full-sib, plantain-derived diploid $\mathrm{F}_{1}$ hybrids TMPx 1668-7 and TMPx 2829-62 were used as female parents in crosses with the improved diploid banana SH 3362 and the cultivated diploid banana 'Pisang lilin'. Also, TMPx 2829-62 was selfed to produce an $\mathrm{F}_{2}$. Figure 1 illustrates the crosses and indicates their parentage and progeny identification. These two TMPx clones were selected in 1990 from crosses between the triploid French plantain cultivar Bobby Tannap (BT) from Cameroon (Swennen, 1990) with the wild diploid banana 'Calcutta 4' (C4), a true-breeding line from Burma/Myanmar (Simmonds, 1953). C4 belongs to the subspecies burmannicoides of M. acuminata Colla. (De Langhe and Devreux, 1960). 'Pisang lilin' is an edible diploid banana of Malaysia (Simmonds, 1966) related to $M$. acuminata ssp. malaccensis. SH 3362 is an improved diploid line developed by Phil Rowe (Fundación Hondureña de Investigación Agricola, Honduras) and kindly provided to IITA. This clone was selected in the third cycle of phenotypic recurrent selection (PRS) in a diploid banana breeding population (Stover and Buddenhagen, 1986). PRS was based mainly on agronomic traits such as bunch weight, fruit size and weight, plant height, and disease resistance (Rowe, 1990).
(Buddenhagen, 1987). Considering the importance of this disease, the International Institute of Tropical Agriculture (IITA) initiated genetic analysis. Simmonds (1986) claimed control of recessive-additive alleles at three loci. Black sigatoka, an airborne fungal lea spot disease, is the most critical constraint to plantain and banana production worldide

\begin{tabular}{|c|c|c|}
\hline \multicolumn{3}{|c|}{$\begin{array}{c}\text { 'Bobby Tannap' } \\
\text { (AAB plantain) }\end{array}$} \\
\hline $\begin{array}{l}\text { SH-3362 } \\
\text { (FHA improved AA diploid) } \\
\text { Segrogaling populations: } \\
\text { TMPX } 14980\end{array}$ & $\begin{array}{r}\text { TMPx 1668-7, TMPx 2829-62 } \\
\text { (diploid plantain-derived hybrids) } \\
\downarrow \begin{array}{r}\downarrow \text { selfed } \\
0 \quad \text { TMPX } 18173\end{array} \\
\end{array}$ & 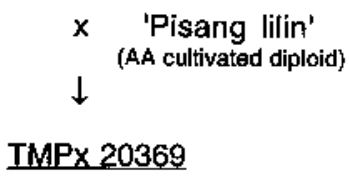 \\
\hline $\begin{array}{l}\text { Total } \\
\text { No. seeds }\end{array}$ & 41 & 150 \\
\hline $\begin{array}{l}\text { Seeds with } \\
\text { embryos }\end{array}$ & 15 & 103 \\
\hline
\end{tabular}

Fig. 1. Pedigree of diploid Musa progenies segregating for albinism. 
Breeding, Cultivars, Rootstocks, \& Germplasm Resources

\section{Results and Discussion}

Albinos, i.e., seedlings that show complete lack of chlorophyll in any plant tissue (Fig. 2), were recovered from the three segregating populations. To our knowledge, this is probably the first report on the occurrence of albinism in the genus Musa. The segregation ratios observed in the three progenies (Table 1) suggest that albinism may be under the genetic control of independent recessive allele(s). Independent tests for goodness of fit were performed using Yates' correction factor for continuity in small sample sizes, which protects against type I errors. Analysis of segregation data of TMPx 14980 and TMPx 18173 progenies were inconclusive to determine whether one or two genes were involved. This failure may be explained by the small sample sizes of these populations, a problem inherent to the low reproductive fertility of cultivated parthenocarpic Musa. However, analysis of data from the TMPx 20369 progeny was unequivocal. The segregation ratio for albinism fit the 15:1 ratio $\left(\chi^{2}=0.07, P=0.79\right)$ and not the $3: 1$ ratio $\left(\chi^{2}=11.02, P<0.01\right)$, suggesting that albinism in Musa species is under the genetic control of at least two independent recessive alleles at two loci (hereafter referred to as $a_{1}$ and $a_{2}$ ) with complementary gene action. This finding was further corroborated by the test for goodness of fit of the pooled results, which was performed after verifying the distribution homogeneity of the three segregating populations (Table 1). This test provided more statistical evidence to reject the hypothesis of a onelocus model (3 normal : 1 albino) and not to reject the two recessive complementary gene hypothesis (15 normal : 1 albino) for the genetic control of albinism in Musa.

'Calcutta 4' is a true-breeding line (Simmonds, 1953). Therefore, it cannot be a carrier of the $a_{1}$ and $a_{2}$ alleles. The necessary inference that its hybrid progenies TMPx 16687 and TMPx 2829-62 are heterozygous for

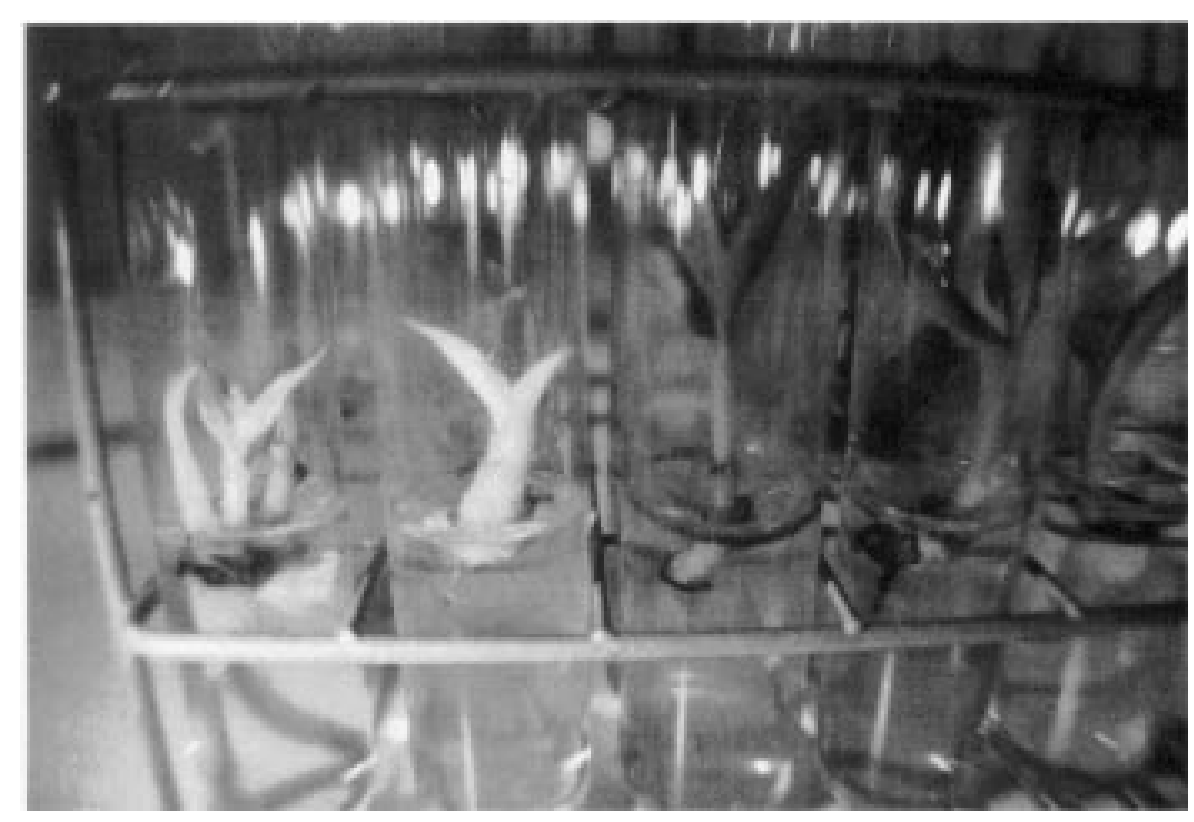

Fig. 2. Albino seedlings of the TMPx $18173 \mathrm{~F}_{2}$ progeny, growing in vitro. sizes, where $\chi^{2}=[\mid \text { Obs. }- \text { Exp.|-0.5 }]^{2} /$ Exp.

both loci indicates that the female plantain parent BT is a carrier of such recessive alleles. This conclusion is corroborated by the earlier observation of an in vitro-produced phenotypic variant (Vuylsteke et al., 1991) of BT that exhibited a chimeric white band on the green pseudostem. That BT is a carrier of recessive deleterious alleles is possible due to two facts: BT's triploidy and its vegetative propagation. Triploidy allows for at least one dominant normal allele $\left(A_{1}\right.$ or $\left.A_{2}\right)$ to mask the deleterious phenotypic expression of the recessive deleterious mutants $\left(a_{1}\right.$ and $\left.a_{2}\right)$. The accumulation of recessive deleterious alleles and of such epistatic genetic systems is expected in vegetatively propagated species (Crow and Kimura, 1965), particularly in view of the occurrence of a series of independent mutational events that accumulated during the long history of Musa cultivation in Africa (De Langhe, 1964).

That 'Pisang lilin' is a carrier of the deleterious recessive alleles for albinism could be expected, because this clone has been described as a structural hybrid (Hutchinson, 1966). Vakili (1965) and R. Ortiz (unpublished data) also found that 'Pisang lilin' was heterozygous for the loci examined. Surprisingly, $\mathrm{SH} 3362$, the improved $2 \mathrm{x}$ progenitor, is also a carrier of the recessive deleterious $a_{1}$ and $a_{2}$ alleles. This finding could indicate that the gain of phenotypic recurrent selection applied to diploid banana improvement has been based on the elimination of deleterious reces-

Table 1. Segregation for green and albino seedlings in three populations of plantain-banana hybrids.

\begin{tabular}{|c|c|c|c|c|c|c|c|}
\hline \multirow[b]{2}{*}{ Population } & \multicolumn{3}{|c|}{ No. germinated seedlings } & \multicolumn{2}{|c|}{ One gene model ${ }^{2}$} & \multicolumn{2}{|c|}{ Two genes model } \\
\hline & Total & Green & Albino & $\chi_{(3: 1)}^{2}$ & $P_{(3: 1)}$ & $\overline{\chi_{(15: 1)}^{2}}$ & $P_{(15: 1)}$ \\
\hline TMPx 14980 & 27 & 25 & 2 & 3.57 & 0.06 & 0.02 & 0.89 \\
\hline TMPx 18173 & 8 & 6 & 2 & 0.17 & 0.68 & 2.13 & 0.14 \\
\hline TMPx 20369 & 64 & 60 & 4 & 11.02 & 0.00 & 0.07 & 0.79 \\
\hline Pooled results $y$ & 99 & 91 & 8 & 14.23 & 0.00 & 0.30 & 0.58 \\
\hline
\end{tabular}

${ }^{2}$ Chi-square tests for goodness of fit were calculated using Yates' correction for continuity in small sample

${ }^{y}$ Test for homogeneity of ratio of the three populations was not significant $\left(\chi^{2}=3.85, P=0.15\right)$.

sive alleles or, in other words, on the accumulation of favorable alleles through recurrent cycles of phenotypic selection. However, heterozygosity seems to be important in the development of elite $2 x$ progenitors because $\mathrm{SH}$ 3362 is a heterozygous clone not only for the $a_{1}$ and $a_{2}$ loci but also for another 20 out of 21 loci examined (R. Ortiz, unpublished data).

In conclusion, this albinism study in Musa hybrids illustrates that population improvement at the $2 \mathrm{x}$ level is effective for eliminating deleterious recessive alleles in selected $2 \mathrm{x}$ progenitors for further crosses with cultivated $3 \mathrm{x}$ bananas or plantains.

Finally, the production of diploid plantainderived hybrids via triploid $x$ diploid crosses not only allows the possibility of plantain germplasm enhancement at the diploid level but also provides the material required for simple genetic analyses in a triploid crop that historically has been neglected for such basic studies (Buddenhagen, 1987).

\section{Literature Cited}

Buddenhagen, I.W. 1987. Disease susceptibility and genetics in relation to breeding of bananas and plantains, p. 95-109. In: G.J. Persley and E.A. De Langhe (eds.). Banana and plantain breeding strategies. Proc. Intl. Wkshp., Cairns, Australia, 13-17 Oct. 1986. ACIAR Proc. no. 21. Australian Centre for Intl. Agr. Res., Canberra.

Crow, J.F. and M. Kimura. 1965. Evolution in sexual and asexual populations. Amer. Natl. 99:439-450.

De Langhe, E. 1964. The origin of variation in the plantain banana. Mededelingen Landbouwhogeschool Gent 29:45-80.

De Langhe, E. and M. Devreux. 1960. Une sousespèce nouvelle de Musa acuminata Colla. Bul. Jard. Bot. Brux. 30:375-388.

Hutchinson, D.J. 1966. Translocation configurations in a diploid banana. Can. J. Genet. Cytol. 8:184-187.

Ortiz, R. and D. Vuylsteke. 1992. Inheritance of black sigatoka resistance and fruit parthenocarpy in triploid AAB plantain. Agron. Abstr. p. 109.

Ortiz, R. and D. Vuylsteke. 1994. Inheritance of black sigatoka disease resistance in plantainbanana (Musa spp.) hybrids. Theor. Appl. Genet. (In press.)

Rowe, P.R. 1990. New genetic combinations in breeding bananas and plantains resistant to diseases, p. 114-123. In: R.L. Jarret (ed.). Identification of genetic diversity in the genus Musa. Proc. Intl. Wkshp., Los Banos, Philippines, 510 Sept. 1988. Intl. Network for the Improvement of Banana and Plantain, Montpellier, France.

Simmonds, N.W. 1953. Segregations in some diploid bananas. J. Genet. 51:458-469.

Simmonds, N.W. 1966. Bananas. 2nd ed. Longman, London and New York. 
Simmonds, N.W. 1986. Bananas, Musa cvs., p. 17 24. In: N.W. Simmonds (ed.). Breeding for durable resistance in perennial crops. FAOTechnical Papers 70. Food and Agr. Organization, Rome.

Stover, R.H. and I.W. Buddenhagen. 1986. Banana breeding: Polyploidy, disease resistance and productivity. Fruits 41:175-191.

Swennen, R. 1990. Limits of morphotaxonomy: Names and synonyms of plantain in Africa and elsewhere, p. 172-210. In: R.L. Jarret (ed.) Identification of genetic diversity in the genus Musa. Proc. Intl. Wkshp., Los Banos, Philippines, 5-10 Sept. 1988. Intl. Network for the
Improvement of Banana and Plantain, Montpellier, France.

Swennen, R. and D. Vuylsteke. 1990. Aspects of plantain breeding at IITA, p. 252-266. In: R.A. Fullerton and R.H. Stover (eds.). Sigatoka leaf spot diseases of bananas. Proc. Intl. Wkshp., San José, Costa Rica, 28 Mar.-1 Apr. 1989. Intl. Network for the Improvement of Banana and Plantain, Montpellier, France.

Swennen, R. and D. Vuylsteke. 1993. Breeding black sigatoka resistant plantains with a wild banana. Trop. Agr. (Trinidad) 70:74-77.

Vakili, N.G. 1965. Fusarium wilt resistance in seedlings and mature plants of Musa species. Phytopathology 55:135-140.

Vuylsteke, D., R. Ortiz, C. Pasberg-Gauhl,F. Gauhl, C. Gold, S. Ferris, and P. Speijer. 1993a. Plantain and banana research at the International Institute of Tropical Agriculture. HortScience 28:873-874, 970-971.

Vuylsteke, D., R. Swennen, and E. De Langhe. 1991. Somaclonal variation in plantains (Musa spp. AAB group) derived from shoot-tip culture. Fruits 46:429-439.

Vuylsteke, D., R. Swennen, and R. Ortiz. 1993b. Development and performance of black sigatokaresistant tetraploid hybrids of plantain (Musa spp., AAB group). Euphytica 65:33-42. 